This item was submitted to Loughborough's Research Repository by the author.

Items in Figshare are protected by copyright, with all rights reserved, unless otherwise indicated.

\title{
Geographies of education and learning
}

PLEASE CITE THE PUBLISHED VERSION

http://dx.doi.org/10.1111/j.1475-5661.2012.00542.x

\section{PUBLISHER}

Wiley-Blackwell on behalf of Royal Geographical Society, with the Institute of British Geographers (@) The Authors)

VERSION

AM (Accepted Manuscript)

LICENCE

CC BY-NC-ND 4.0

REPOSITORY RECORD

Holloway, Sarah L., and Heike Jons. 2019. "Geographies of Education and Learning”. figshare. https://hdl.handle.net/2134/13795. 
This item was submitted to Loughborough's Institutional Repository (https://dspace.lboro.ac.uk/) by the author and is made available under the following Creative Commons Licence conditions.

\section{creative
commons}

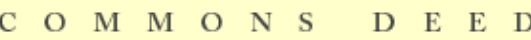

Attribution-NonCommercial-NoDerivs 2.5

You are free:

- to copy, distribute, display, and perform the work

Under the following conditions:

Attribution. You must attribute the work in the manner specified b the author or licensor.

Noncommercial. You may not use this work for commercial purposes.

No Derivative Works. You may not alter, transform, or build upon this work.

- For any reuse or distribution, you must make clear to others the license terms of this work.

- Any of these conditions can be waived if you get permission from the copyright holder.

Your fair use and other rights are in no way affected by the above.

This is a human-readable summary of the Leqal Code (the full license).

\section{Disclaimer 만}

For the full text of this licence, please go to: http://creativecommons.org/licenses/by-nc-nd/2.5/ 


\section{Geographies of education and learning}

\section{To cite: Holloway, S.L. \& Jöns, H. (2012) Geographies of education and learning Transactions of the Institute of British Geographers 37.4: 482-88}

\section{Framing the field}

In the twenty-first century Anglophone geographers have exhibited a growing interest in education and learning (Holloway et al., 2010). Geographies of education and learning consider the importance of spatiality in the production, consumption and implications of formal education systems from pre-school to tertiary education and of informal learning environments in homes, neighbourhoods, community organisations and workspaces. Between them, these geographies foreground the wider political, economic, social and cultural processes shaping and being reshaped through formal and informal spaces of education across the globe, and the ways they are experienced, embraced and contested by educators and diverse subjects of education, including children, young people, parents, and workers (subject positions which clearly are not mutually exclusive). In so doing, geographies of education and learning need to examine the historical and contemporary policies and experiences of education and consider their un/intended impacts in creating particular types of citizens as well as (paid and unpaid) workers for the future. This requires that we look into different education and learning spaces, and examine the links between these and other facets of life in diverse (and inter-related) local, national and transnational contexts.

This definition is both summative and prospective: it draws together threads evident in geographical writing, at the same time as it sets an agenda for research in this heterogeneous but emerging field. Current Anglophone interest in geographies of education and learning is evidenced in numerous conference sessions at international geographical meetings and in the Second International Conference on Geographies of Education at Loughborough University where this Boundary Crossing will be presented. These new English-language geographies of education and learning have precursors in previous Anglophone debates and in a variety of spatial research traditions in other language contexts, and they intersect with interdisciplinary debates about knowledge, education and skills (Meusburger, 2010). Different sub-disciplinary traditions within human geography have shaped their emergence and the field includes researchers who are defined here as producing geographies of education and learning but who might not apply this label to themselves. This multiplicity of roots is reflected in review pieces 
that are noteworthy for their variety, often addressing markedly different literatures and audiences (compare Holloway et al., 2010; Power and Malmberg, 2008).

This piece, which acts as an editorial introduction to a Virtual Issue, brings together papers from these diverse trajectories that have appeared in the pages of Transactions. Our discussion is organised around four key themes that emerge in the field: educational provision and restructuring; subjectivities in diverse learning spaces; skills, employability and careers; mobility and networks. In each case we trace the emergence of research on this theme; what this work brings to our understanding of education and learning; and where future research agendas might usefully take us. In so doing, we situate the fourteen Transactions articles that constitute the Virtual Issue within these wider debates.

\section{Educational provision and restructuring}

States play an important role in the provision of formal education. Their role in locational decisions (e.g. school expansion/closure programmes; the foundation of new universities) was a key concern for mainland European geographers from the 1970s (Meusburger, 1998). In Anglophone geography this European tradition was largely ignored, but twenty-first century restructuring of neoliberal welfare states has seen growing interest in the topic. This reflects the rise of education up the political agenda in the Global North, where discursive priority is now attached to education in policy as it is seen to underpin national economic competitiveness in global knowledge economies, at the same time as it enhances social cohesion by giving individuals the skills to confront this changing world (Jenson and St Martin, 2006). Consequent neoliberal educational restructuring has seen a reshaping of services across the sector (Basu, 2007, Smith et al., 2008). Future research needs to balance contemporary interest in the changing form of educational provision with attention to its changing functions, whilst drawing out the importance of shifts in the nature of neoliberalism in times of financial austerity and the changing nature of provision outside the Global North.

Debates about educational restructuring have been played out in the pages of Transactions in two distinct ways. One group of authors have concentrated on the state, emphasising both its spatiality and its (heterogeneous) contested and contingent nature. Mahon (2005, 2006) emphasises the multi-scalar nature of the state, showing how outcomes in childcare availability diverge between and within states. Understanding of the contested nature of state policy is developed by Dwyer and Parutis (2012, Virtual Issue) who trace -- through research with religious organisations -- how pressure groups 
can reinterpret and sometimes subvert government policy. The importance of the peopling of the state is emphasised by Holloway and Pimlott-Wilson (2012, Virtual Issue), who demonstrate that local-state actors' classed and gendered ideas matter, as they in part shape how national policies are implemented in practice, consequently shaping geographically uneven service provision. Kraftl (2012, Virtual Issue), by contrast, explores the ideas and practices of those parents who have rejected state provision and chosen instead to home-school their children. This interest in unpacking the state and uncovering the localisation of policy in practice needs to be extended beyond the Global North, for example, as in Ansell's (2010) study on children and youth as policy subjects in Lesotho's education sector.

All stages of education are marked by inequalities in access to provision. A second set of authors have exposed the ways in which less well-off and some ethnic minority students are disadvantaged in terms of access to high-quality school and university education (Hamnett and Butler, 2011, Virtual Issue; Harris, 2012, Virtual Issue; Singleton, 2010). The intractability of problems in equitable access to state education is apparent when we consider the results of schemes directly designed to address this (Allen et al., 2012, Virtual Issue). In the Global South too, education has been prominent in policy as a 'solution' to development (Jones and Chant, 2009), but multiple axes of social difference, as well as urban/rural divides, continue to shape access to school education (Baschieri and Falkingham, 2009; da Cunha et al., 2009). Comparative research on access, aspirations and attainment in diverse cultural contexts offers valuable lines of enquiry in this area, research which could benefit from mixed methods approaches that combine statistical techniques with discourse analysis and qualitative interviewing.

\section{Subjectivities in diverse learning spaces}

Access to education is an important issue, but so too is what is learnt. School, university and life-long learning curricula can influence the development of regional, national and transnational identities in future citizen-workers (King and Ruiz-Gelices, 2003). Mitchell (2003) argues that in the era of globalisation shifts in the relationship between state formation and economic organisation have produced changes in the types of multicultural citizens education systems in the Global North are seeking to produce. Pyckett et al. (2010: 489) urge caution, however, using a case study on global citizenship education to point out that neoliberal programmes do not always succeed in changing people's subjectivities, not least as these are 'performed moving through multiple spatial-temporal domains’ rather than being solely shaped within particular 
institutions such as schools. Understanding of the multi-scalar nature of citizenship education, in this instance religious citizenship, is developed by Hemming (2011, Virtual Issue), who shows how wider discourses about nation, which are embedded in local communities and educational institutions, intersect with mundane practices in the everyday micro spaces within schools. Indeed, the importance of multiple time-spaces is further emphasised when we consider learning environments outside formal education, as in Mills' (2012, Virtual Issue) historical study of the Scouting movement as a space in civil society where ideas about citizenship can be communicated to a far from passive group of young people.

Geographers have also examined how formal and informal curricula within education spaces can be important in the (re)production of intersecting axes of social differences, such as class, gender, race, religion, sexuality and dis/ability, influencing students' experiences of education in the present and their future life-worlds (Holt, 2007; Jeffrey, 2008; Riley and Ettlinger, 2011). This is at least in part because attitudes to childhood and youth, and particular types of pupils and students, shape the design of educational services and spaces as well as the ways in which they are used by educators and learners (Kraftl, 2006; Reh et al., 2011). Interestingly, these different avenues of research come together in Hopkins' (2011, Virtual Issue) article that explores how national policies and geopolitical considerations shape Muslim students’ embodied and everyday experiences in the institutional space of a university campus.

Future research under this theme will benefit from the confluence of interest in 'geographical' and social identities and the spaces of learning through which they are in part constituted. These spaces of learning should, as Mills (2012) demonstrates, include the informal alongside longer standing interest in formal learning environments, elucidating their role in the making of socio-spatial identities and networks. Moreover, it will be necessary to look more closely at the ways in which the different worlds of home, (pre-)school/college/university and informal spaces of learning coalesce in shaping the lives of individuals. This might usefully be complemented by studies that examine the links between learning about social positions, formal qualifications, and their application in work-life contexts.

\section{Skills, employability and careers}

The employability of students is a priority for universities across the world, and particularly in Europe, where the Bologna process has introduced undergraduate and postgraduate degrees that reflect the British model (Hennemann and Liefner, 2010). 
Geographical research in the Global North has been relatively slow to explore this theme, but there is much to be learned from research in the Global South, which highlights the problems young people experience in turning school and higher education qualifications into labour market opportunities (Jeffrey et al., 2005; Jones and Chant, 2009; Punch, 2004). Drawing on this lead, future work could trace the career trajectories of school leavers and graduates, comparing, for example, the impact education has in the future life chances of different social groups; the relative importance of educational capital (certified qualifications) and social capital (personal networks) in securing employment in different cultural contexts; and the impact of other factors, including current and anticipated domestic responsibility, in shaping transitions from education to employment. For graduates, this question can be closely linked to the value that academic degrees from different countries, and within nations from institutions with different reputational standings, have for an individual's employability.

It is noteworthy that in the pages of Transactions the entangled relations between education, learning and work have been addressed by new economic geographers, whose contribution offers something subtly different to our understanding of education. Jones (2011, Virtual Issue) discusses the importance of workplace learning outside formal educational contexts. His analysis highlights how the skills young people acquire through gap year voluntary work, and the value attached to these by graduate employers, equip them to compete more effectively for global corporate work. By contrast, Hall (2008, Virtual Issue), draws our attention to flows of knowledge, as she traces the circular nature of ideas and practices taught in higher education MBA programmes and used in corporate finance practice. Some corporate valuation techniques can be taught in MBA classrooms and directly transferred into practice in London's financial district, but other softer skills (understanding firms' notions of best practice; embodied experience of corporate valuation in different contexts) are learnt in the workplace. This has resulted in a flow of knowledge back into higher education institutions, causing MBA providers 'to reposition themselves both materially and discursively closer to economic, and particular financial services, practice' (Hall, 2008: 38). These links between educational institutions and their wider context is something we reflect on in more detail below.

\section{Mobility and networks}

Educational institutions are constituted by complex networks that are created and maintained by incoming and outgoing mobility of its students and staff, and by diverse flows of knowledge, information, capital and resources. Recent geographical research 
examines these from two perspectives: the impact of educational institutions on their local and regional environment; and processes and practices of internationalisation. In the immediate urban context, research has considered the changes universities bring to local housing and retail markets through processes of studentification (Smith, 2008). In the wider urban and regional context, questions have been asked about universities' contribution to innovation and economic development through university graduates and the production of knowledge that can be transferred into regional business opportunities (Lawton Smith 2006; Power and Malmberg, 2008). This first line of inquiry, not yet represented in the pages of Transactions, would benefit from bringing together the social and economic dimensions of local and regional interactions generated through educational institutions. Further research also needs to compare the impact different types of educational institutions have on their localities, and consider these in their wider socio-cultural contexts (see, for example, Heffernan and Jöns 2007).

Geographical research on the internationalisation of education has mainly focused on student mobility, as increasing numbers of students travel abroad to study at school or university. These movements include both short-term credit mobility (Findlay et al., 2006) and longer-term school/degree-mobility (Brooks and Waters, 2011). The latter has received increasing attention as neoliberal restructuring has prompted educational institutions in many countries to attract fee-paying international students in order to sustain and develop their sector in times of fiscal difficulty (Madge et al., 2009). Waters' (2006, Virtual Issue) Bourdieusian research on flows between Hong Kong and Canada has been key in highlighting how middle-class groups are seeking to ensure their children gain cultural capital, and thus positional advantage in the labour market, through the accrual of overseas educational qualifications (see also Huang and Yeo, 2011). This practice is not confined to East-West flows, however, and Findlay et al. (2012, Virtual Issue) show how flows within the Global North are part of a wider mobility culture that facilitates the international careers of a transnational capitalist class. Other recent work widens the spatial frame to Central Asia, and broadens the debate from class reproduction alone, showing how this is experienced through gender, sexuality and religion (Holloway and Pimlott-Wilson, 2012). Indeed, this interest in gender has a longer heritage in research on academic mobility, where Jöns (2009, 2011) has explored how different cultural contexts shape the career chances of men and women working in higher education, providing them with more or less opportunities for participating in transnational academic mobility and thus for generating often beneficial outcomes. Leung's (2012, Virtual Issue) recent work builds on both this and 
Bourdieusian work on student mobility (Waters, 2006) to understand the experience of Chinese academics who have undertaken research visits to Germany.

Over the past two decades, practices of internationalization in higher education have diversified and become a priority on many higher education agendas (Olds, 2007). World-class institutions have refined their core business to promote their status in global rankings, sometimes deepening their connections with other world-class universities in the process, as well as extending their spatial reach through a proliferation of branch campuses (Hoyler and Jöns, 2008). Transnational academic programs, university networks, and school exchange programmes are further examples for internationalisation strategies in education that require geographical analysis in a wider project to map the increasingly globalised nature of higher education, thereby usefully complementing growing research on transnational academic mobility of students, educators, researchers and academics.

\section{New geographies of education and learning}

This critical intervention has identified a body of work that can justifiably be labelled 'new geographies of education and learning' as it is intra- and inter-disciplinary as well as increasingly international in terms of knowledge producers and sites of study. To expand, there is a long tradition of geographies of education in non-English language contexts, notably in mainland Europe, the importance of which has not always been acknowledged in recent Anglophone work. As the research discussed in this Virtual Issue shows, much recent English-language work has emerged from diverse subdisciplinary interests. These studies complement geographical research traditions in other language contexts, for example, through a focus on neoliberal restructuring of education, but their diverse intra-disciplinary roots also mean they take the agenda in different directions and therefore constitute a related but profoundly different body of work.

These multiple strands of research in geography’s different language traditions are, we contend, currently coming together in new geographies of education and learning. This process is being facilitated by the long-term mobility of academics, as well as through short-term movements for events such as conferences. The Second International Conference on Geographies of Education at Loughborough, for example, where half the delegates are from a diversity of nations outside of the UK, acts as a platform to support these knowledge flows. Moreover, these new geographies are interdisciplinary because they have engaged with broader social sciences, just as the 
spatial turn in these disciplines has encouraged interest in geographies of education and learning (see, for example, Cook and Hemming, 2011; Waters and Brooks, 2011).

The papers collected in this Virtual Issue are primarily from British geographers, often with a UK focus, reflecting Transactions' position as the journal of the Royal Geographical Society with the Institute of British Geographers, and the particular moment in the origin of these new debates. In the future, we suggest that there is scope for developing new geographies of education and learning in ways that consider different cultural contexts, global landscapes of education, and comparative perspectives. As we begin to see in this collection of papers, the comparative approach should not be restricted to contemporary geographical dimensions but include: historical comparisons; further explorations of the relative importance of diverse axes of social difference; and examinations of different educational sectors and types of institutions (including vocational training and professional development). Such comparative geographies require attention to the relationship between formal and informal spaces of education and learning as well as to the value of different forms of education for future life chances. Finally, this agenda necessitates a comparison of how perceptions, practices and power-relations amongst policy makers, educators and learners shape the geographies of education and learning.

\section{Acknowledgements}

Sarah Holloway is a British Academy Mid-Career Fellow and gratefully acknowledges this support. Thanks to Sarah Mills, Helena Pimlott-Wilson and an anonymous referee for their comments.

\section{References}

Allen R, Burgess S and McKenna L 2012 The short-run impact of using lotteries for school admissions: early results from Brighton and Hove's reforms Transactions of the Institute of British Geographers

Ansell N 2010 The discursive construction of childhood and youth in AIDS interventions in Lesotho's education sector: beyond global-local dichotomies Environment and Planning D: Society and Space 28 791-810

Baschieri A and Falkingham J 2009 Staying in School: Assessing the Role of Access, Availability, and Economic Opportunities - the Case of Tajikistan Population Space and Place 15 205-24 
Basu R 2007 Negotiating acts of citizenship in an era of neoliberal reform: the game of school closures International Journal of Urban and Regional Research 31 109-27

Brooks R and Waters J 2011 Student Mobilities, Migration and the Internationalization of Higher Education Basingstoke: Palgrave Macmillan

Cook VA and Hemming PJ 2011 Education spaces: embodied dimensions and dynamics Social \& Cultural Geography 12 1-8

da Cunha JMP, Jimenez MA, Rus Perez JR and de Andrade CY 2009 Social segregation and academic achievement in state-run elementary schools in the municipality of Campinas, Brazil Geoforum 40 873-83

Dwyer C and Parutis V 2012 'Faith in the system?' State-funded faith schools in England and the contested parameters of community cohesion Transactions of the Institute of British Geographers

Findlay A M, King R, Smith F M, Geddes A. and Skeldon R 2012 World class? An investigation of globalisation, difference and international student mobility. Transactions of the Institute of British Geographers 37 118-131

Findlay A, King R, Stam A, Ruiz-Gelices E 2006 Ever reluctant Europeans - The changing geographies of UK students studying and working abroad European Urban and Regional Studies 13 291-318

Hall S 2008 Geographies of business education: MBA programmes, reflexive business schools and the cultural circuit of capital Transactions of the Institute of British Geographers 33 27-41

Hamnett C and Butler T 2011 'Geography matters’: the role distance plays in reproducing educational inequality in East London Transactions of the Institute of British Geographers 36 479-500

Harris R 2012 Geographies of transition and the separation of lower and higher attaining pupils in the move from primary to secondary school in London Transactions of the Institute of British Geographers

Heffernan M and Jöns $\mathbf{H} 2007$ Degrees of influence: the politics of honorary degrees in the Universities of Oxford and Cambridge, 1900-2000 Minerva 45 389-416 
Hemming PJ 2011 Educating for religious citizenship: multiculturalism and national identity in an English multi-faith primary school Transactions of the Institute of British Geographers 36 441-454

Hennemann S and Liefner I 2010 Employability of german geography graduates: The mismatch between knowledge acquired and competences required Journal of Geography in Higher Education 34 215-230

Holloway SL and Pimlott-Wilson H 2012 Neoliberalism, policy localisation and idealised subjects: a case study on educational restructuring in England Transactions of the Institute of British Geographers

Holloway SL, Hubbard P, Jöns, H and Pimlott-Wilson H 2010 Geographies of education and the importance of children, youth and families Progress in Human Geography 34 583-600

Holloway SL, O’Hara SL and Pimlott-Wilson H 2012, Educational mobility and the gendered geography of cultural capital: the case of international student flows between Central Asia and the UK Environment and Planning A

Holt L 2007 Children's socio-spatial (re)production of disability within primary school playgrounds Environment and Planning D: Society and Space 25 783-802

Hopkins P 2011 Towards critical geographies of the university campus: understanding the contested experiences of Muslim students Transactions of the Institute of British Geographers 36 157-169

Hoyler M and Jöns H 2008 Global knowledge nodes and networks, in C. Johnson, R. Hu and S. Abedin (Eds) Connecting Cities: Networks Sydney: Metropolis, 124-51.

Huang S and Yeoh BSA 2011 "Navigating the terrains of transnational education: children of Chinese ‘study mothers’ in Singapore” Geoforum 42 394-403

Jeffrey C 2008 Kicking away the ladder: student politics and the making of an Indian middle class Environment and Planning D: Society and Space 26 517-36

Jeffrey C, Jeffrey P and Jeffrey R 2005 When schooling fails: young men, education and low-caste politics in rural north India Contributions to Indian Sociology 39 1-38 
Jenson J and Saint-Martin D 2006 Building blocks for a new social architecture: the LEGOTM paradigm of an active society. Available from: http://www.cccg.umontreal.ca/pdf/997 jenson rev 03, last accessed 1.11.10.

Jones A 2011 Theorising international youth volunteering: training for global (corporate) work? Transactions of the Institute of British Geographers 36 530-544

Jones GA and Chant S 2009 Globalising initiatives for gender equality and poverty reduction: Exploring 'failure' with reference to education and work among urban youth in The Gambia and Ghana Geoforum 40 184-96

Jöns H 2011 Transnational academic mobility and gender Globalisation, Societies, and Education 9 183-209

Jöns H 2009 ‘Brain circulation’ and transnational knowledge networks: studying longterm effects of academic mobility to Germany, 1954-2000. Global Networks 9 315-338

King R and Ruiz-Gelices E 2003 International student migration and the European 'year abroad': effects on European identity and subsequent migration behaviour. International Journal of Population Geography 9 229-52

Kraftl P 2006 Building an idea: the material construction of an ideal childhood Transactions of the Institute of British Geographers 31 488-504

Kraftl P 2012 Towards geographies of 'alternative' education: a case study of UK home schooling families Transactions of the Institute of British Geographers

Lawton Smith H 2006 Universities, Innovation and the Economy London: Routledge

Leung MWH 2012 'Read ten thousand books, walk ten thousand miles’: geographical mobility and capital accumulation among Chinese scholars Transactions of the Institute of British Geographers

Madge C Raghuram P and Noxolo P 2009 Engaged pedagogy and responsibility: a postcolonial analysis of international students Geoforum 40 34-45

Mahon R 2005 Rescaling social reproduction: childcare in Toronto/Canada and Stockholm/Sweden International Journal of Urban and Regional Research 29 341-57

Mahon R 2006 Of scalar hierarchies and welfare redesign: child care in three Canadian cities Transactions of the Institute of British Geographers 31 452-466 
Meusburger P 1998 Bildungsgeographie: Wissen und Ausbildung in räumlicher Dimension Heidelberg: Spektrum Akademischer Verlag

Meusburger P 2010 Knowledge, Geography of, in Warf B ed. Encyclopedia of Geography Thousand Oaks: Sage 1659-1664

Mills S 2012 “An Instruction in Good Citizenship”: Scouting and the Historical Geographies of Citizenship Education Transactions of the Institute of British Geographers

Mitchell K 2003 Educating the national citizen in neoliberal times: from the multicultural self to the strategic cosmopolitan Transactions of the Institute of British Geographers 28 387-403

Olds K 2007 Global assemblage: Singapore, foreign universities, and the constructions of a 'Global education hub’ World Development 35 959-75

Power D and Malmberg A 2008 The contribution of universities to innovation and economic development: in what sense a regional problem? Cambridge Journal of Regions, Economy and Society 1 233-45

Punch S 2004 The Impact of Primary Education on School-to-work Transitions for Young People in Rural Bolivia Youth \& Society 36 163-182.

Pykett J, Cloke P, Barnett C, Clarke N, Malpass A 2010 Learning to be global citizens: the rationalities of fair-trade education Environment and Planning D: Society and Space 28487 - 508

Reh S, Rabenstein, K and Fritzsche, B 2011 Learning spaces without boundaries? Territories, power and how schools regulate learning Social \& Cultural Geography 12 83-98

Riley C and Ettlinger N 2011 Interpreting Racial Formation and Multiculturalism in a High School: Towards a Constructive Deployment of Two Approaches to Critical Race Theory Antipode 43 1250-80

Singleton AD 2010 The geodemographics of educational progression and their implications for widening participation in higher education Environment and Planning A 42 2560-80 
Smith DP 2008 The politics of studentification and '(un)balanced' urban populations: lessons for gentrification and sustainable communities? Urban Studies 45 2541-2564

Smith F, Barker J, Wainwright E, Marandet E and Buckingham S 2008: A new deal for lone parents? Training lone parents for work in West London. Area 40 237-44.

Waters J and Brooks R 2011 International/transnational spaces of education Globalisation, Societies and Education 9 155-160

Waters JL 2006 Geographies of cultural capital: education, international migration and family strategies between Hong Kong and Canada Transactions of the Institute of British Geographers 31 179-192 